\title{
RCA Analysis on Norwegian Salmon Exports to China
}

\author{
Jing Ma \\ School of Economics and Management, Changchun University of Science and Technology \\ No. 7989 Weixing Road, Changchun 130022, China \\ E-mail: majingdoll@hotmail.com \\ Jing Xiao \\ School of Economics and Management, Changchun University of Science and Technology \\ No. 7989 Weixing Road, Changchun 130022, China \\ E-mail: christieshaw@sohu.com
}

\begin{abstract}
The purpose of this paper is to analyze the comparative advantage of salmon products from Norway in China salmon market compare with other main salmon exporting countries, such as Chile, Canada Japan and U.S.A. Firstly, we give a general introduction of Norwegian salmon exports, then we apply Balassa's Revealed Comparative Advantage index and modify it according to this case, then make analysis on the basis of calculated RCAs.
\end{abstract}

Keywords: Norwegian salmon, China, RCA

\section{Norwegian Salmon Industry Overview}

Norway is the leading producer and exporter of Atlantic salmon in the world. The salmon farms are spread out along the long coastline with its many fjords, inlets and islands, which in combination with stable water temperatures $\left(4-15^{\circ} \mathrm{C}\right)$ and good infrastructure provide an excellent environment for salmon farming. Atlantic salmon is sold fresh, frozen, as fillets, smoked and cured. Fish farmed salmon dominates, and fresh whole salmon is the main export product and accounts for about three quarters of the total value of exports. Norway also exports 2 billion NOK worth of salmon fillets. The fact that the Norwegian salmon exports amounted to 96 kilos per inhabitant in 2004 gives a perspective of the size of the industry (Statistics Norway). Norwegian farmed salmon was sold to 94 countries, whereas $90 \%$ is exported to 19 countries (Trondsen, 2005). The main exporting markets of Norwegian salmon are EU like Denmark, France, Germany and Japan in Asia. EU, however, implemented a price restriction (price floor) on imported salmon one decade ago, which left no more room for price reduction by Norwegian exporters. Meanwhile the competitive pressure from the Scottish salmon producers led Norwegian exporters to look for other markets to deal with the continuously increased production, but not be highly dependent on EU market (Trond Bjørndal, et al, 2003). China, with big seafood consumption capability, is one of the target markets for many Norwegian fishery exporting companies. While Norwegian salmon sells pretty well in Japanese market, the Chinese neighborhood country because of the consumption habit, food tradition, and economy condition, and so on. The Norwegian share of Japanese salmon market was at its peak with $71 \%$ in 2002 (Elin Helene Sissener, 2005)

\section{Salmon Demand Condition in China}

The overall export of Norwegian seafood product to China is much more than salmon; it also includes mackerel and white fish. Mackerel is exported to China for processing and mostly goes to the Japanese market. White fish also is processed in China and transported back to European market, so the Norwegian seafood product which is being consumed in China indeed and what is important for branding Norwegian seafood and Norway is Norwegian salmon.

With the growth of China's economy and living conditions, Chinese people are getting richer with higher consumption level and the demand for seafood increases rapidly year after year. According to collected data, Chinese urban people will consume seafood twice more in five years than today, as more and more Chinese are moving from the countryside to live in the cities; this will push it up still further. (Seafood International, 2007) Among plenty kinds of seafood, salmon is very popular in Chinese market with abundant nutrition and very 
good flavor. And Norwegian salmon is called "fish king in icy ocean" in China, and enjoy greater and greater popularity for its unique taste. Thus the salmon consumed in China are mainly imported abroad. Now China is the third largest importer of Norwegian salmon in Asian countries, following Japan and Chinese Hong Kong. Norwegian salmon by far has the majority of the market, as over $90 \%$ of the market is Norwegian salmon, and also over $90 \%$ of salmon market is fresh. Undoubtedly with the biggest population in the world, China has absolutely a big potential consumption market for Norwegian salmon. Norwegian salmon are getting more and more accepted by Chinese young people, especially the middle-class population due to its particular taste. The high price is not a big problem actually, because sometimes high price also means high quality. Chinese consumers are sensitive to product quality, so any hike in income will therefore increase the demand for high-quality seafood. Actually salmon was a kind of luxury product 10 years ago in China, but salmon consumption nowadays increases rapidly by $10 \%$ yearly with the same speed as the GDP of China. So that means the promotion of Norwegian salmon goes quite well in China especially in some big cities. Actually the potential of 1.3 billion populations is really a big attraction for Norwegian exporters, but of course not everybody has the capability to consume. But imagine if just $10 \%$ of the population consume Norwegian salmon, and if each person eat one piece of salmon per year, that is a big number already. Also the growing Chinese market is not saturated yet presently. The following table is Norwegian salmon and trout exports value and volume to China in 2005 and 2006. So we can see the changing tendency of exporting salmon and trout from Norway to China during this couple of years. And it can reflect the fluctuating price of salmon and trout as well. The reason here data of salmon and trout are displayed together is that they both are called "red fish", that is to say they both belong to this category. Whereas for Norwegian exports to China salmon is always in the absolute leading position compare with trout.

\section{Competitiveness Analysis}

\subsection{Norway and its Competitors per Category of Salmon Products}

The annual rate of the value of the exports of all types of salmon from Norway to China growth is about $7.9 \%$. In absolute terms, the value of salmon exports to China is not very large, but the potential of this huge market is enormous. As our analysis below shows, it makes little sense to treat salmon as a single category when considering the competition that Norway faces. The data show clearly that fresh salmon and frozen salmon constitute different markets from the point of view of competition with other countries. That indicates that Norway competes with other salmon exporting countries in several different categories.

Actually China imports salmon not only from Norway but also from some other countries which have a well developed aquaculture industry, such as Chile. The competition from Chile has been paid particular attention as an essential issue by the Norwegian salmon stakeholders. Although over 20 yeas ago salmon was not produced in Chile, the salmon production is one of the most important industries of the country currently, and Chile ranks second in the world, following Norway in salmon production. The consciousness of quality, brand and country image help Chilean salmon obtain high reputation in international market. Actually Chile learns quite a lot about fish farming techniques from Norway and got large amount of Norwegian investments and technology transfer in the aquaculture industry.

Furthermore China and Chile signed a bilateral free trade agreement in South Korea on 18th November 2005, which is the first free trade agreement between China and a Latin American country and also represents the long term business connection of the two countries. According to the China-Chile free trade agreement, smoked salmon has five-year free tariff for entering into China market, while fresh salmon and frozen salmon enjoy ten-year tax holiday. This strategy is worth being considered because it suggests how to deal with the salmon trade between China and Norway.

Actually free trade agreement between China and Chile is a kind of competition for Norwegian salmon's exporting to China, but the main exported salmon from Chile to China is frozen salmon, not fresh one, so they compete in different categories. And Canada is an emerging competitor of Norwegian salmon in the China market, whereas Canada is not that famous for salmon, with its relative small exports to China. Many Chinese consumers think salmon only means Norway.

Here we classify salmon into four categories: FAS: fresh Atlantic salmon; OFS: other fresh salmon; RAS: frozen Atlantic salmon; ORS: other frozen salmon. Our first category, fresh Atlantic salmon shows the following general picture: Norway is the sovereign exporter, whose exports to China dwarf the exports of all other countries together. The quantity imported from Chile (the main importer of frozen salmon) has become insignificant during the last years. The import of fresh salmon from Norway is skyrocketing, at the annual rate of increase of $124 \%$ while the other countries show no increase at all. Norwegian fresh salmon goes up almost as 
total China imports of fresh salmon. Yet in absolute value, it still does not represent a large value of exports, less than 18 Million dollars in 2005. As regards the second category, other fresh salmon, it is a small market in China, (less than $10 \%$ of the fresh Atlantic salmon market), and a declining market as well. Here also, Norway dominates but its imports in that category are sharply declining, as the Atlantic salmon seems to impose itself as the leading category of fresh salmon. The frozen Atlantic salmon market, our third category, is also an increasing market for Norway. While the total imports of this category of salmon increased at the rate of about $15 \%$ a year, the Norwegian share increased at the rate of about $40 \%$ a year. It is still a very small market, worth only about 2 Million $\$$ in total and only $\$ 250,000$ for Norway in 2005 . Fresh salmon is, by its nature, not re-exported, and the country where fresh salmon is produced is also the one from which it is exported to China. The same is not true for frozen salmon. Japan produces salmon by itself also, but there is still one reason to suspect that some imports, from Japan for example, represent fish which is being re-exported. As the figure shows, the largest importer of frozen salmon is Chile, whose imports are still modest but growing fast. The last category, frozen other salmon, a market of about $\$ 6$ Million, which seems to be dominated by the U.S.A. salmon, and seemingly re-exported salmon from Japan. The Norwegian contribution is insignificant.

Fresh Atlantic salmon is the largest and most promising market segment for Norway. Frozen salmon seems to be loosing its market share to Chile. The other segments are small and declining. Yet, in absolute value, the Norwegian imports are still modest. Next we give a more detailed analysis of the relative position of the different categories of salmons for each one of the main exporters to China, using an index which is meant to measure each exporter's relative competitiveness.

\subsection{Revealed Comparative Advantage (RCA) Analysis per Salmon Product}

We are going to examine the relative comparative advantage of the main exporters of salmon to China at supplying it with a particular kind of salmon product. We shall use an index that was inspired by Balassa's "revealed comparative advantage" (RCA) index, a widely used tool in international trade studies. (Dr Gwo-Jiun Mike Leu, 1998)

In fact, before Balassa introduced his famous RCA index in 1965, Liesner (1958) had already contributed to the empirical literature of RCA. In this sense, Liesner (1958) is the first empirical study in the area of RCA. The proposed simple measure of RCA by Leisner is the following:

$$
\mathrm{RCA}=\mathrm{Xij} / \mathrm{Xnj}
$$

Where $\mathrm{X}$ represents exports, $\mathrm{i}$ is a country, $\mathrm{j}$ is a commodity (or industry), and $\mathrm{n}$ is a set of countries (e.g. the EU). A more advanced measure of RCA was later on presented by Balassa (1965). This is a widely accepted modified measure of RCA in the literature. (Utku Utkulu and Dilek Seymen, 2004) The Balassa's RCA index is calculated according to the formula:

$$
\operatorname{RCAXij}=(\mathrm{Xij} / \mathrm{Xi}) /(\mathrm{Xwj} / \mathrm{Xw})
$$

Where $\mathrm{Xij}$ is total country $\mathrm{i}$ export of product $\mathrm{j}$ to the world market; $\mathrm{Xi}$ is total country $\mathrm{i}$ export of all the products to the world market; Xwj is total world export of product $\mathrm{j}$; $\mathrm{Xw}$ is total world export of all the products. This formulation can measure the international competitiveness of country $i$ in the production of product $j$.

Inspired by the above index, we are here going to analyze the relative comparative advantage, for some exporting country, of exporting one kind of salmon product relative to all salmon product to one country, here China. The index is defined as follows:

$$
\mathrm{RCA} * \mathrm{Xij}=(\mathrm{Xij} / \mathrm{Xi}) /(\mathrm{Cij} / \mathrm{Cw}) \text {. }
$$

Like Balassa's index, it is "revealed" in the sense that it is based on observed trade. Here, Xij is total China imports of a particular salmon product $\mathrm{j}$ from country $\mathrm{i}$; $\mathrm{Xi}$ is total China salmon imports from country $\mathrm{i}$; $\mathrm{Cij}$ is the total China imports of salmon product $\mathrm{j}$; and $\mathrm{Cw}$ is the total China salmon imports. It shows the relative export competitiveness of salmon product $\mathrm{j}$ from country $\mathrm{i}$ in the China salmon market. The relative competitiveness of product $\mathrm{j}$ will go up with the value of RCAs (RCAXij indices). If a RCA* is more than 1, that means that, for salmon product $j$, country $i$ imports to China a larger proportion of product $j$ than of salmon in general than all the importers of salmon to China do. This indicates that country $i$ has a comparative advantage at exporting to China salmon product $\mathrm{j}$ rather than other salmon products.

We illustrate with an example. China is the importing country. Suppose that the exporting country is Norway and the salmon product is fresh Atlantic salmon. If the ratio $\mathrm{Xij} / \mathrm{Xi}=0.95$, this means that $95 \%$ of the value of the salmon exports from Norway to China is fresh Atlantic salmon. If now, $\mathrm{Cij} / \mathrm{Cw}=0.55$, this means that the total Chinese import of fresh Atlantic salmon is $55 \%$ of the Chinese import of all salmon products. Then RCA*Xij $=$ 
$0.95 / 0.55=1.73$. This indicates that Norway has, within the "imports of salmon to China" category, a substantial relative comparative advantage at exporting to China fresh Atlantic salmon rather than all salmon products as a whole. Had the ratio been less than 1, it would have indicated the opposite.

We figure out the RCA*s for the main exporters of salmon to China from 2002 to 2005. In 2005 there was a very good sign of revealed comparative advantage (1.43 on fresh Atlantic salmon, 1.616 on other fresh salmon) of Norwegian fresh salmon in the China market compared with other competitors. Canada had a downward tendency of RCA*s on fresh Atlantic salmon whereas it hit 5.815 on other fresh salmon. A potential competition from Canada on fresh salmon is getting bigger. And comparative disadvantage on exporting frozen salmon to China from Norway was figured out by very small number just a little bit above 0 . For fresh Atlantic salmon, Norway has very stable RCA*s over 1 within the observed four years which indicates constant revealed comparative advantage in the China fresh Atlantic salmon market and the only meaningful competitor - Canada goes up and down in RCA*s from year to year, and fell down to 0.494 and lost comparative advantage in 2005 due to the competition from Norway. For other fresh salmon, Norway shows its revealed comparative advantage by RCA*s being over 1.3 for three years, although it was not very optimistic in 2004 but anyway at least over 0.8. Although Canada and Japan have large and unstable RCA*s, Canada has very good comparative advantage in 2005, therefore comes a competitive signal to Norway. Then figure obviously shows the Norway's comparative disadvantage in exporting frozen Atlantic salmon to China, as RCA*s are just a little bit above zero, as well as Japan (but it was better in the year of 2005). While Denmark's high degree of RCA*s does not mean high export capability, but because little other salmon products come to China, i.e. numerator of the formulation (Xij/Xi) is equal or almost equal to one. U.S.A's comparative advantage in the first three years was getting smaller in 2005 with a downward tendency. Chile's RCA*s were very unstable in observed years; However it is extremely high in 2005, which could be a good sign for its future frozen salmon trade with China.

\section{Summary}

In this paper we can see Norway competes with other main salmon exporting countries in different kinds of categories. Refer to Balassa's Revealed Comparative Advantage model, we utilize RCA*s to compare salmon exporting comparative advantage within main salmon exporting countries in China. RCA*s indicate that Norway maintains the leading position of exporting fresh salmon to China for several years and also with an upward tendency, while in frozen salmon market it never shows significance in history compare with Chile.

\section{References}

[Online] Available: www.foodqs.com. (China Food Network) visited in 2006.

[Online] Available: www.seafoodchina.com. visited in 2006.

Balassa, B. (1965). Trade Liberalization and Revealed Comparative Advantage. The Manchester School, 33, P99-123.

Bjørndal Trond, Gunnar A. Knapp, and Audun Lem. (2003). Salmon-A study of Global Supply and Demand. SNF-Report No. 40/03.

Gwo Jiun Mike Leu. (1998). Changing Comparative Advantage in East Asian Economies. [Online] Available: http:// www.ntu.edu.sg/nbs/sabre/working_papers/03-98.pdf.

Liesner, H. H. (1958). The European Common Market and British Industry. The Economic Journal, Vol. 68, No. 270, P 302-316.

Seafood international. (2007). China uncovered an industry revolution.

Sissener, Elin H., Trond Bjørndal, and Frank Asche. (2003). EFTA frihandelsavtaler-døråpnerer for norsk fiskeeksport? En analyse av handelsmønstre mellom Norge og tredjeland og virkningene av Eus kom pensasjonskvoter. Bergen. Samfunns og næringslivsforskning as.

Trondsen, T. (2005). Key success factors for performance of the Chinese international fish value chain- a cooperative research project. in Lindkvisit, K.B (Ed.). The Chinese Seafood Industry, SNF-report No. 20/05.

Utku Utkulu and Dilek Seymen. (2004). Revealed Comparative Advantage and Competitiveness. Dokuz Eylul University. Economics Department. Izmir. 